\title{
Finite Element Analysis on Axial Bearing Capacity of Square Double Skin Steel Stub Short Columns Filled with Recycled Concrete
}

\author{
Song Bing \\ Department of Structural Engineering \\ Yanbian University \\ Yanji,China \\ bing901102@163.com
}

\begin{abstract}
Based on the compressive strength experiment of vitrified micro bubbles (VMB) recycled concrete double mixed diatomite calcined and fly ash,this paper adopts the finite element software ANSYS to analyze the impacts of different hollow ratio and VMB content on axial bearing capacity of square double skin steel stub short columns filled with recycled concrete in condition of $100 \%$ recycled coarse aggregate replacement ratio and $3 \%$ diatomite calcined content.The result shows that:Compressive strength of VMB recycled concrete increases with the increase of diatomite calcined content from 0 to $3 \%$, when the content of diatomite calcined is $3 \%$,compressive strength of the $130 \% \mathrm{VMB}$ content test specimen can reach 32.45 MPa; When the hollow components reach ultimate bearing capacity, their axial displacement decrease by $5.6 \%$ compared to solid components, improving buckling capacity and ductility of components; When the VMB content is same,ultimate bearing capacity of hollow components compared to solid components increase by $2.5 \%$; When the hollow ratio is same,ultimate bearing capacity of the $130 \%$ VMB content component compared with $0 \%$ content component only reduces by $3.5 \%$; By means of the regression analysis of the component axial pressure data,we have exported bearing capacity of square double skin steel stub short columns filled with recycled concrete under axial compression.
\end{abstract}

Keywords-square double skin steel stub filled with recycled concrete;diatomite calcined;vitrified micro bubbles;axial bearing capacity;finite element analysis

\section{INTRODUCTION}

In recent years, vitrified micro bubbles is widely used as a new sort of environment-friendly and inorganic lightweight insulation materials, which can be used to make the VMB recycled concrete when it is added into the recycled concrete. Its strength and thermal insulation property can reach the ideal performance that is tested by the experiment[1].Recycled concrete filled square steel tubes (CFST) is the structure style casting recycled concrete into the steel pipe, core concrete bears three directions force due to the restraint of the steel tube, improving the bearing performance and the recycled concrete engineering application value;Besides the same advantages with CFST, concrete filled double-skin steel tube(CFDST)could also expand cross section, with a higher bending rigidity lighter weight and better performance in earthquake resistant and fire resistant.Compared with those structural parts in style of SHS outer and SHS inner, SHS outer and CHS inner has better malleability[2-4].

\author{
Li BaiShou \\ Department of Structural Engineering \\ Yanbian University \\ Yanji,China \\ bsli@ybu.edu.cn \\ * Corresponding Author
}

Therefore, based on the compressive strength experiment of vitrified micro bubbles (VMB) recycled concrete double mixed diatomite calcined and fly ash,this paper adopts the finite element software ANSYS to analyze the impacts of different hollow ratio and VMB content on axial bearing capacity of square double skin steel stub short columns filled with recycled concrete, in condition of $100 \%$ recycled coarse aggregate replacement ratio and $3 \%$ diatomite calcined content,and we have exported bearing capacity of square double skin steel stub short columns filled with recycled concrete under axial compression.

\section{GENERAL SITUATIONS OF EXPERIMENT}

\section{A. Experiment of VMB Recycled Concrete}

Experiment uses 42.5 ordinary Portland cement; recycled coarse aggregate with a broken jaw crusher whose screening particle size is $5 \sim 20 \mathrm{~mm}$, bulk density is $1280 \mathrm{~kg} / \mathrm{m} 3$ and bibulous rate is $4.8 \%$; sand fineness modulus is 2.9; fly ash uses the original ash from Yanji heating plant, basically reaching the level II for fly ash fineness requirements; Jilin Linjiang Tianyuan catalyst co.LTD., production of 325 mesh diatomite calcined, its performance parameters are shown in table 1 ; VMB produced by Linghai City Longyan Building Materials Factory,stacking density is $128 \mathrm{~kg} / \mathrm{m} 3$ whose performance parameters are shown in table 2;poly carboxylic acid high efficiency water reducing agent produced by Yenji Fangsheng Building Materials Company, water reducing rate is $25 \%$ or higher, which contains $0.8 \%$ of gas composition;mixing water is ordinary tap water.

After trial mixing,eventually water-binder ratio of $\mathrm{VMB}$ recycled concrete mixture ratio is 0.45 , sand ratio is $30 \%$. Results of each test block of experiment parameters and maintenance of indoor after curing $28 \mathrm{~d}$ are shown in table 3 .

Conclusions according to table 3: when the diatomite calcined content is same, increasing the VMB content, or when the dosage of VMB is same, increasing diatomite calcined content, the compressive strength of concrete both have a trend of increase; when diatomite calcined is $3 \%$ and the dosage of VMB is $130 \%$, compressive strength of block is $32.45 \mathrm{MPa}$ and its density is just $1942.45 \mathrm{~kg} / \mathrm{m} 3$, compared with the ordinary concrete dry apparent density of $2000 \sim 2500 \mathrm{~kg} / \mathrm{m} 3$, it can achieve reducing building self quality and improving anti-seismic performance. 
TABLE I. PERFORMANCE OF DIATOMITE CALCINED AND VITRIFIED MICRO BUBBLES

\begin{tabular}{|c|c|c|c|c|c|c|c|c|c|}
\hline \multicolumn{5}{|c|}{ Performance of diatomite calcined } & \multicolumn{5}{|c|}{ Performance of vitrified micro bubbles } \\
\hline $\begin{array}{c}\mathrm{Fe}_{2} \mathrm{O}_{3} \\
\mathrm{Content} \\
1 \%\end{array}$ & $\begin{array}{c}\mathrm{S}_{\mathrm{i}} \mathrm{O}_{2} \\
\text { Content } \\
/ \%\end{array}$ & $\begin{array}{c}\text { Specific } \\
\text { surface } \\
\text { area } \\
/\left(\mathrm{cm}^{2} / \mathrm{g}\right)\end{array}$ & $\begin{array}{c}\text { Ignition } \\
\text { loss } \\
1 \%\end{array}$ & $\begin{array}{c}\text { Bulk } \\
\text { density } \\
/\left(\mathrm{g} / \mathrm{cm}^{3}\right)\end{array}$ & $\begin{array}{l}\text { grain } \\
\text { size } \\
/(\mathrm{mm})\end{array}$ & $\begin{array}{l}\text { Density } \\
/\left(\mathrm{kg} / \mathrm{m}^{3}\right)\end{array}$ & $\begin{array}{c}\text { thermal } \\
\text { conductivity } \\
/[W /(m \cdot k)]\end{array}$ & $\begin{array}{l}\text { Surface } \\
\text { vitrified } \\
\quad 1 \%\end{array}$ & $\begin{array}{c}\text { Water } \\
\text { absorption } \\
1 \%\end{array}$ \\
\hline$\leq 1.5$ & $\geq 92$ & $\begin{array}{c}600 \\
\text { thousand }\end{array}$ & $\leq 0.5$ & $\leq 0.42$ & $0.5 \sim 1.5$ & $50 \sim 200$ & $0.0284 \sim 0.054$ & $\geq 95$ & $20 \sim 50$ \\
\hline
\end{tabular}

TABLE II. THE VMB RECYCLED CONCRETE EXPERIMENTAL PARAMETERS AND TEST RESULTS

\begin{tabular}{|c|c|c|c|c|c|c|c|c|c|c|}
\hline \multirow{2}{*}{$\begin{array}{c}\text { Test } \\
\text { specimen } \\
\text { number }\end{array}$} & \multicolumn{8}{|c|}{ Material utilization amount/ $\left(\mathrm{kg} / \mathrm{m}^{3}\right)$} & \multirow{2}{*}{$\begin{array}{c}\text { Compressive } \\
\text { strength } \\
/ \mathrm{MPa}\end{array}$} & \multirow{2}{*}{$\begin{array}{l}\text { Dry density } \\
/\left(\mathrm{kg} / \mathrm{m}^{3}\right)\end{array}$} \\
\hline & Cement & Fly ash & $\begin{array}{c}\text { Diatomite } \\
\text { calcined }\end{array}$ & $\begin{array}{l}\text { Recycled } \\
\text { coarse } \\
\text { aggregate }\end{array}$ & Sand & $V M B$ & $\begin{array}{l}\text { water } \\
\text { reducer }\end{array}$ & water & & \\
\hline BRC-0-3 & 349.11 & 93.5 & 14.2 & 1171.35 & 504 & 0 & 10.38 & 206 & 34.5 & 2118.05 \\
\hline BRC-100-3 & 458.18 & 122.6 & 18.4 & 1114.95 & 479.5 & 127.8 & 13.51 & 270 & 30.8 & 1969.35 \\
\hline BRC-100-2 & 464.3 & 122.6 & 12.31 & 1114.95 & 479.5 & 127.8 & 13.51 & 270 & 26.49 & 1965.43 \\
\hline BRC-100-0 & 476.49 & 122.6 & 0 & 1114.95 & 479.5 & 127.8 & 13.51 & 270 & 22.36 & 1909.12 \\
\hline BRC-130-3 & 458.19 & 122.6 & 18.4 & 1114.95 & 479.5 & 154 & 13.51 & 270 & 32.45 & 1942.45 \\
\hline BRC-130-2 & 464.25 & 122.6 & 12.31 & 1114.95 & 479.5 & 154 & 13.51 & 270 & 27.56 & 1910.28 \\
\hline BRC-130-0 & 476.49 & 122.6 & 0 & 1114.95 & 479.5 & 154 & 13.51 & 270 & 25.95 & 1923.42 \\
\hline
\end{tabular}

Note: BRC-130-3,BRC represents VMB recycled concrete, 130 represents the VMB volume contains in the total volume is $130 \%, 3$ represens that the diatomite calcined content is

\section{B. Design of test specimens}

In order to study CFDST, length of the test specimen must be proper, length-width ratio of the test specimen is 3[5].Steel type is Q235, cross section form is shown in figure 1,main parameters of test specimens are shown in the table $3, \chi=D_{i} /(B-2 t), \xi=A_{\text {so }} f_{y} /\left(A_{c o} f_{c k}\right)$, in the formula, Aso is the outer steel pipe cross-sectional area, fy is outer steel pipe yield strength,Aco is the area contained by the outer steel tube,fck is standard value of recycled concrete compressive strength.

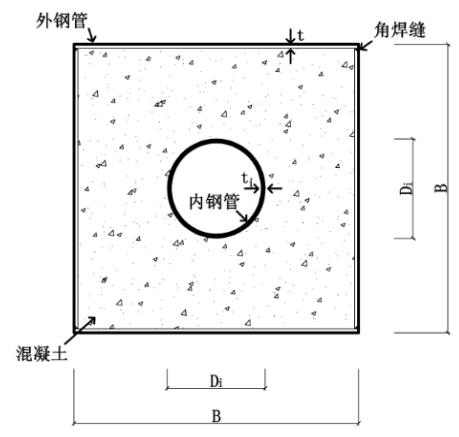

Figure 1. Cross section diagram of test Specimen

TABLE III. TEST SPECIMEN NUMBER AND MAIN PARAMETERS

\begin{tabular}{|c|c|c|c|c|c|c|c|}
\hline $\begin{array}{c}\text { Test specimen } \\
\text { number }\end{array}$ & $\begin{array}{l}\mathrm{B} \times \mathrm{t} \times \mathrm{L} \\
/\left(\mathrm{mm}^{3}\right)\end{array}$ & $\begin{array}{c}\mathrm{D}_{\mathrm{i}} \times \mathrm{t}_{\mathrm{i}} \\
/\left(\mathrm{mm}^{2}\right)\end{array}$ & $\begin{array}{l}\text { Hollow } \\
\text { ratio } \chi\end{array}$ & $\begin{array}{c}\text { Confining } \\
\text { factor } \xi\end{array}$ & $\begin{array}{c}F_{\mathrm{y}} \\
/(\mathrm{MPa})\end{array}$ & $\begin{array}{c}F_{\mathrm{cu}} \\
/(\mathrm{MPa})\end{array}$ & $\begin{array}{r}N_{\text {ANSYS }} \\
/(\mathrm{kN}) \\
\end{array}$ \\
\hline S-K1-0 & $180 \times 2.5 \times 540$ & $\longrightarrow$ & & 0.5891 & \multirow{6}{*}{235} & 34.5 & 1110 \\
\hline S-K1-100 & $180 \times 2.5 \times 540$ & $\longrightarrow$ & 0 & 0.6599 & & 30.8 & 1008 \\
\hline S-K1-130 & $180 \times 2.5 \times 540$ & - & & 0.6265 & & 32.45 & 1061 \\
\hline S-K2-0 & $180 \times 2.5 \times 540$ & $62 \times 2.5$ & & 0.5891 & & 34.5 & 1126 \\
\hline S-K2-100 & $180 \times 2.5 \times 540$ & $62 \times 2.5$ & 0.35 & 0.6599 & & 30.8 & 1041 \\
\hline S-K2-130 & $180 \times 2.5 \times 540$ & $62 \times 2.5$ & & 0.6265 & & 32.45 & 1090 \\
\hline
\end{tabular}

mean VMB content accounted for $0 \% 、 100 \%$ and $130 \%$ of the total concrete volume. 


\section{ESTABLISHMENT OF THE FINITE ELEMENT MODEL}

\section{A. The selection of element types}

Steel uses the Solid45 element to simulate, Es=2.06 $\times$ $105 \mathrm{MPa}, \mathrm{Vs}=0.3$;Concrete uses the Solid65 element to simulate, elastic modulus is calculated by recycled concrete elastic modulus formulas that is put forward by the reference [6], $\mathrm{Vt}=0.2$.

$$
E_{C}=\frac{10^{5}}{2.2+34.7 / \mathrm{fcu}} /(0.2811 \delta+1.065)
$$

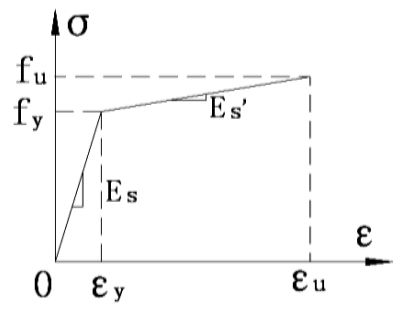

(a)Uniaxial model of steel

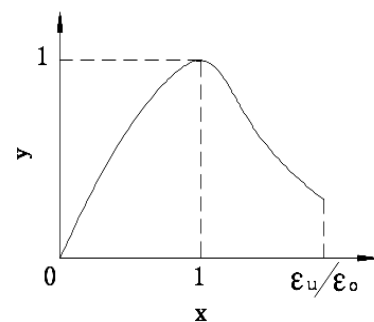

(b)Uniaxial model of concrete
Figure 2. Material stress-strain relations

\section{Modeling and Meshing}

Regardless of slip between core concrete and steel tube, we add $15 \mathrm{~mm}$ rigid plate in order to prevent the phenomenon of stress concentration on both ends of pillars.Quality of meshing directly affects the precision and speed of calculation, so hexahedron unit division side length of solid 45 and solid65 are $15 \mathrm{~mm}$. As shown in Fig.3.

\section{Control of Convergence}

\section{1) Loading and boundary conditions}

We add axial load on the upper plate, which generated by the rigid plate into uniformly distributed load on the model, at the same time we add $\mathrm{x}, \mathrm{y}, \mathrm{z}$ three directions of displacement constraints on the column bottom plate.

\section{2) Concrete crush Settings}

The open crack of concrete shear transfer coefficient and closed joint shear transfer coefficient are respectively set as 0.35 and 0.9 , axial tensile strength is $3 \mathrm{MPa}$, close the concrete crush option.

\section{3) Nonlinear analysis options}

Open the large deformation of static analysis and the automatic time step length, number of substeps is set as
In the formula: $\delta$ represents the replacement rate of recycled coarse aggregates, $f_{c u}$ is the cube compressive strength of concrete.

\section{B. Constitutive relations of materials}

\section{1) Constitutive relation of steel}

The steel uses dual linear kinematic hardening model (BKIN), which is shown in the figure 2 (a).

\section{2) Constitutive relation of concrete}

Literature research has shown that in the case of small hollow rate,mechanical properties of CFDST and CFST are similar. Therefore,this paper uses the theory[7] that core recycled concrete stress-strain relationship model, as shown in figure 2 (b).

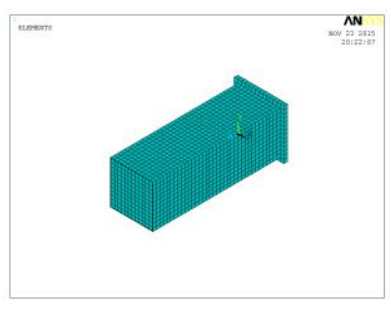

(a) CFST

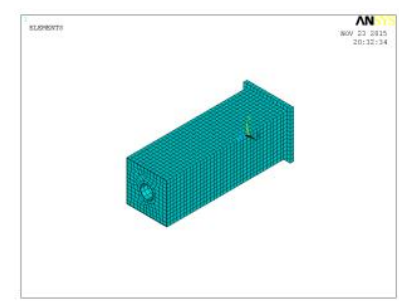

(b) CFDST
Figure 3. Finite element model

200 , maximum equilibrium iteration times is set as 40 , the Newton - Laposen ( $\mathrm{N}-\mathrm{R}$ method) is used to solve and convergence tolerance is set as 0.05 .

\section{CALCULATED RESULTS ANALYSIS OF FINITE ELEMENT}

\section{A. Strain and displacement analysis of test specimens}

Fig .4. is the strain and displacement nephogram of test specimen S-K1-130 and S-K2-130 that have arrived the ultimate bearing capacity. As shown in Fig .4. (a) and (b), axial strain of the components corner in the end of load and constraint is apparently greater than other regions, especially the middle is apparently greater than its adjacent areas, local buckling occurs, axial displacement is $1.7 \mathrm{~mm}$; as shown in Fig .4. (c) and (d), hollow components appear the local buckling,but do not change apparently in the middle, which indicates the inner steel tube can prevent or delay local buckling of the component, axial displace-ment is $1.605 \mathrm{~mm}$ that decreases by $5.6 \%$ compared with the solid components, setting of inner steel tube enhances the deformation capacity and improving the ductility.

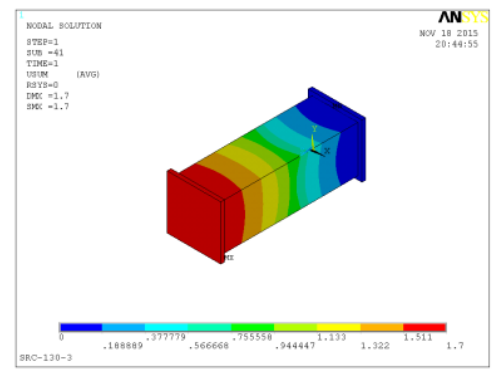

(b) S-K1-130 Displace vector sum 


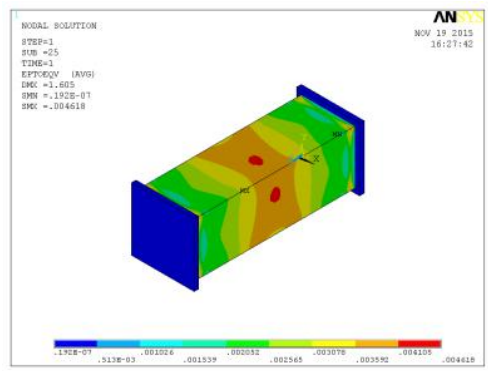

(c) S-K2-130 axial strain nephogram

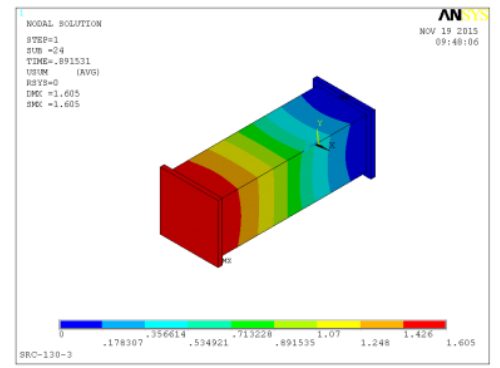

(d) S-K2-130 Displace vector sum

Figure 4. Component strain and displacement nephogram

\section{B. Ultimate bearing capacity analysis of test specimens}

At present, the research on CFST has achieved fruitful results and established regulations at home and abroad,this article uses CECS [8], AIJ [9], EC4[10] technical order and computational formula of ultimate bearing capacity put forward by Dong Jiangfeng[11] to analyze the ultimate bearing capacity of three solid components, and based on the formulas we add inner steel tube bearing capacity as the ultimate bearing capacity computational formula of hollow components. The calculation results compared with the ANSYS finite element values are shown in table 4.

TABLE IV. COMPARISON BETWEEN ANSYS FINITE ELEMENT VALUES

\begin{tabular}{|c|c|c|c|c|c|c|c|c|c|c|c|}
\hline Number & $\begin{array}{c}\text { ANSYS } \\
/ \mathrm{kN}\end{array}$ & $\begin{array}{c}\text { CECS } \\
/ \mathrm{kN}\end{array}$ & $\begin{array}{l}\mathrm{AIJ} \\
/ \mathrm{kN}\end{array}$ & $\begin{array}{l}\mathrm{EC} 4 \\
/ \mathrm{kN}\end{array}$ & $\begin{array}{l}\text { Refer.[11] } \\
/ \mathrm{kN}\end{array}$ & $\frac{N_{\text {ANSYS }}}{N_{C E C S}}$ & $\frac{N_{\mathrm{ANSYS}}}{N_{A I J}}$ & $\frac{N_{\mathrm{ANSYS}}}{N_{E C 4}}$ & $\frac{N_{\text {ANSYS }}}{N_{\text {Refer .11 }}}$ & $\begin{array}{c}\text { Average } \\
\text { value }\end{array}$ & $\begin{array}{l}\text { Standard } \\
\text { deviation }\end{array}$ \\
\hline S-K1-0 & 1110 & 1131 & 1024 & 1269 & 1021 & 0.9814 & 1.0839 & 0.8045 & 1.0871 & 0.9892 & 0.1148 \\
\hline S-K1-100 & 1008 & 1040 & 947 & 1161 & 937 & 0.9692 & 1.0644 & 0.8070 & 1.0757 & 0.9791 & 0.1075 \\
\hline S-K1-130 & 1061 & 1092 & 991 & 1223 & 985 & 0.9716 & 1.0706 & 0.8053 & 1.0771 & 0.9812 & 0.1097 \\
\hline S-K2-0 & 1126 & 1170 & 1074 & 1295 & 1076 & 0.9623 & 1.0484 & 0.8308 & 1.0464 & 0.9720 & 0.0885 \\
\hline S-K2-100 & 1041 & 1089 & 1004 & 1198 & 1001 & 0.9559 & 1.0368 & 0.8355 & 1.0399 & 0.9670 & 0.0831 \\
\hline S-K2-130 & 1090 & 1135 & 1045 & 1254 & 1044 & 0.9594 & 1.0421 & 0.8325 & 1.0431 & 0.9693 & 0.0854 \\
\hline
\end{tabular}

Results of ANSYS analysis are following: When the hollow ratio is same, the ultimate bearing capacity of $130 \%$ VMB component compared with content is $0 \%$ only reduces by $3.5 \%$; When VMB content is same,though CFDST have reduced the amount of concrete,because of the inner steel tube,compared with solid components,their ultimate bearing capacity increase by $2.5 \%$, which reducing weight and enhancing the anti-seismic performance of components;Finite element analysis results and the calculations of CECS,AIJ,EC4 and reference [11] are in good agreement.Through comparative analysis,we have found that adding inner steel tube bearing capacity on the axial compression bearing capacity formula can be used to calculate ultimate bearing capacity of hollow components.

For the thin-walled square steel tube concrete,they refer to the superimposed calculation formula of bearing capacity that considering the local buckling of the bearing capacity of steel tube and concrete after considering constraints[12], bearing capacity of square double skin steel stub short columns filled with recycled concrete is composed by bearing capacity of internal and external steel tube and core concrete.As shown in the formula 2.

$$
N_{\mathrm{u}}=F_{\mathrm{s}}+k A_{c} f_{c k}+A_{s i} f_{y i}
$$

In the formula: $A_{c}$ is section area of core concrete; $A_{s i}$ is section area of inner steel tube; $f_{y i}$ is the yield strength of steel pipe; $f_{c k}$ is standard value of recycled concrete compressive strength; $F_{s}$ is the bearing capacity of the outer steel tube, $B_{e}$ is equal to $D_{e}$ in the square steel tube.

$$
\begin{gathered}
F_{\mathrm{s}}=2 t f_{y}\left(B_{e}+D_{e}\right) \\
B_{e}=7.4 B\left\{\frac{B}{t} \sqrt{\frac{f_{y}}{235}}\right\}^{-0.51}
\end{gathered}
$$

Relationship between strength increase coefficient $\mathrm{k}$ of the core concrete and the effect of restraint coefficient $\xi$ is linear[13].So We did the regression analysis according to the axial pressure data of CFDST are shown in Figure 5.

Mathematical expression of strength increase coefficient $\mathrm{k}$ of the core concrete and the effect of restraint coefficient $\xi$ is presented by the formula 5 .

$$
k=-0.019 \xi+1.0408
$$


Studies have shown that axial compressive properties of hollow and solid components are similar when the hollow rate is in a certain range,but inner steel tube is not binding.So we should subtract concrete bearing capacity of hollow part, if we calculate bearing capacity as a solid component.

$$
\frac{A_{\mathrm{co}}-A_{\mathrm{c}}}{A_{\mathrm{co}}}=\left[\frac{D_{i}}{B-2 t}\right]^{2}=\chi^{2}
$$

In the formula: As is the outer steel pipe cross-sectional area,Ac is the area contained by the outer steel tube, $\chi$ is hollow rate.

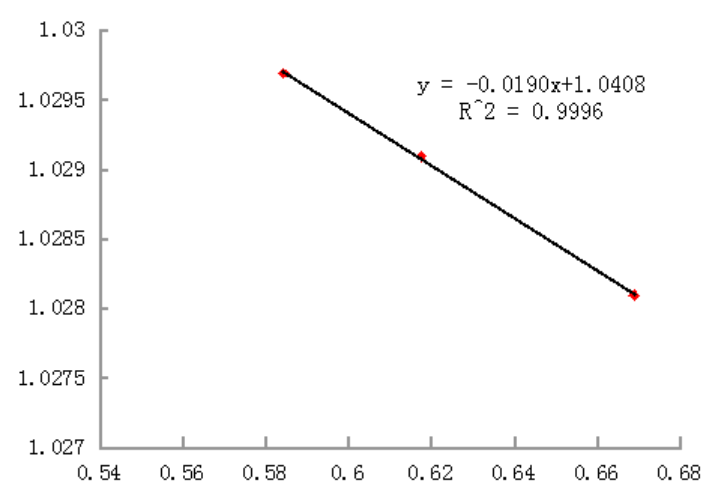

Figure 5. $\xi$-k relation curve charts

\section{CONCLUSIONS}

When the diatomite calcined content is same,with the increase of vitrified micro bubbles content, or when the vitrified micro bubbles content is same,with the increase of diatomite calcined content, compressive strength of recycled concrete shows a trend of increase; When diatomite calcined content is $3 \%$ and vitrified micro bubbles content is $130 \%$,compressive strength of block can reach $32.45 \mathrm{MPa}$, and its density is just $1942.45 \mathrm{~kg} / \mathrm{m} 3$;

Due to the inner steel tube setting of hollow components, when vitrified micro bubbles content is same,ultimate bearing capacity of hollow components compared to solid components increase by $2.5 \%$, which reducing weight as well as improving the anti-seismic performance; their axial displacement compared with solid components decrease by $5.6 \%$ when they reach ultimate bearing capacity, which improving the buckling performance and increasing the ductility of components;

Maximum standard deviations of six CFDST of different hollow rates and vitrified micro bubbles content simulated values and calculated values are 0.1148 and 0.1097,which in good agreement;

Consdering adverse effects of local buckling of big length-width ratio thin-walled SHS tube to ultimate bearing capacity,by means of the regression analysis data,we not only have found that relationship between strength increase coefficient $\mathrm{k}$ of the core concrete and the effect of restraint coefficient $\xi$ is linear,but have exported bearing capacity of square double skin steel stub short
We can export bearing capacity of square double skin steel stub short columns filled with recycled concrete under axial compression when we introduce $\chi$ into formula 2 .

$$
N_{\mathrm{u}}=F_{\mathrm{s}}+\left(1-\chi^{2}\right) k A_{c o} f_{c k}+A_{s i} f_{y i}
$$

When $\chi$ is equal to zero, formula 7 can be used to calculate bearing capacity of square steel tube short columns filled with recycled concrete.Comparison results of simulated values and calculated values by formula 7 are shown in Fig .6.We can see that the calculated values and simulated values are very close and in good agreement.

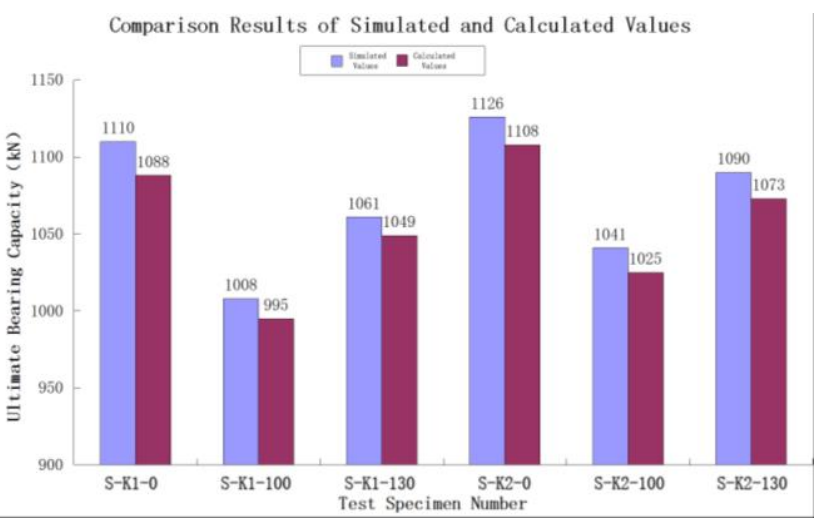

Figure 6. Comparison results of simulated and calculated values

columns filled with recycled concrete under axial compression.

\section{REFERENCES}

[1] Chen Kaihua, Luo Surong, Zheng jianfeng. Cause vitrified microsphere, recycled concrete heat preservation and heat insulation performance testing research [C].The third session of the national academic seminar on recycled concrete. Qingdao, 2012:495-522

[2] Han linhai, Yang Youfu. Modern concrete filled steel tube structure technology [M]. Second edition. Beijing: China Building Industry Press, 2007

[3] Wang Nannan. Hollow interlayer of square concrete-filled steel tube column experiment research and numerical simulation performance [D]. Hebei, Hebei University of Engineering, 2013

[4] YF Yang, LH Han, BH Sun. Experimental behaviour of partially loaded concrete filled double-skin steel tube (CFDST) sections. Journal of Constructional Steel Research, 2011, 71:63-73

[5] Zhong Shantong. Concrete filled steel tube structure [M]. Harbin: Heilongjiang science and technology press, 1994

[6] Zhou Jinghai, He Haijin. Basic mechanical properties of recycled concrete test $[\mathrm{J}]$. Journal of shenyang architectural university (natural science edition), 2010, 26 (3) : 464- 468

[7] Yang Youfu. Recycled concrete filled steel tube components load deformation relations theory analysis $[\mathrm{J}]$. Industrial construction, 2007, 37 (12) : 1-6

[8] CECS 159:2004, Technical specification for rectangular steel tube concrete structures[S].Beijing: China Plan Publishing Company, 2004.

[9] AIJ,1997.Recommendations for design and construction of concrete filled steel tubular structures[S]. Architectural Institute of Japan(AIJ),Tokyo,Japan 
[10] European Committee for Standardization. EuroCode 4:Design of Composite Steel and Concrete Structures-Part1.1:General rules and rules for buildings. 1994

[11] Dong Jiangfeng,Wang Qingyuan. Mechanical behavior of recycled aggregate concrete filled double skin steel tube columns[J]. Journal of building materials, 2014,17(4):627-633

[12] Guo Lanhui,Zhang Sumei.Simplified method of bearing capacity of concrete-filled rectangular steel tube columns considering local bucking subjected to axial compression[J]. Industrial Construction, 2009, 39(7):98-102

[13] Wang Yanze.Axial behavior of square double skin steel stub columns filled with demolished concrete lump[D].Yanji:Yanbian University,2014 